\title{
De gepolitiseerde participant: ideologie en politieke participatie in twintig democratieën
}

Tom van der Meer, Jan van Deth en Peer Scheepers

\section{SAMENVATTING VAN}

Van der Meer, T.W.G., Van Deth, J.W. \& Scheepers, P.L.H. (2009). The Politicized Participant: Ideology and Political Action in 20 Democracies. Comparative Political Studies, 42 (11), 1426-1457.

Het uitgangspunt van ons artikel is de premisse dat moderne democratieën niet alleen een hoge mate van burgerparticipatie vereisen, maar dat participatie in verschillende bevolkingsgroepen in principe ook gelijk dient te zijn. Ongelijke participatie leidt tot een bias in de geuite voorkeuren van de burgers en daarmee mogelijk ook tot een bias van beleidsmakers. Hoewel het idee van gelijkheid zo oud is als de democratie, is politieke participatie in de praktijk zeer ongelijk. Eerder onderzoek richtte zich veelal op ongelijkheid tussen sociaaleconomische en demografische groepen, op basis van onder andere inkomen, opleidingsniveau, leeftijd, geslacht en religie. Ongelijke participatie is echter met name problematisch wanneer verschillende groepen ook verschillende politieke voorkeuren hebben. Juist dan is immers een direct verband tussen ongelijke politieke participatie en bias in de voorkeuren van de beleidsmakers te verwachten. De centrale vraag in ons artikel luidt: in welke mate beïnvloeden de ideologische voorkeuren van burgers hun geneigdheid tot politieke participatie? Ten tweede stellen we de vraag: in hoeverre hangen ongelijkheden in participatie samen met kenmerken van de institutionele omgeving.

Theoretisch maken we een onderscheid tussen enerzijds de prikkels die nodig zijn om te willen participeren en anderzijds de middelen om te kunnen participeren. Vanuit rivaliserende dan wel complementaire theorieën formuleren we hypothesen (zie hieronder) die we vervolgens empirisch toetsen. Voor de empirische analyses gebruiken we de gegevens van de westerse landen in de Comparative Studies of Electoral Systems (CSES), Module 2 (2001-2006). In dit bestand worden de nationale kiezersonderzoeken gecombineerd waarin dezelfde vragen zijn gesteld over onder meer links-rechtspositionering en over zes vormen van politieke participatie (opkomst bij verkiezingen, contact zoeken met beleidsmakers, campagne 
voeren, anderen overtuigen van politieke doelen, samenwerken met een politiek doel, en demonstreren). Aan dit databestand hebben wij zes extra kiezersonderzoeken toegevoegd. Relevante kenmerken van de landen in de analyses zijn: de mate van consensualisme op twee dimensies (cf. Lijphart 1999), de mate van economische ontwikkeling (BBP per hoofd van de bevolking in PPP), en het bestaan van een opkomstplicht. Om de gegevens over 47.902 kiezers tijdens 27 verkiezingen in 20 landen simultaan te analyseren, gebruiken we multivariate multiniveauanalyses.

Allereerst is het verband tussen ideologische voorkeur en politieke participatie onderzocht, waarbij drie aspecten van ideologische voorkeur onderscheiden worden: extremisme, linkse versus rechtse voorkeuren en ideologische afstand tot de regering. De eerste hypothese is dat ideologisch extreme burgers politiek actiever zijn dan gematigde burgers, doordat 'extremisten' zich daartoe meer geprikkeld voelen. Op grond van de empirische analyses vinden we steun voor deze hypothese voor alle zes vormen van politieke participatie.

De tweede hypothese luidt dat linkse burgers politiek actiever zijn dan rechtse burgers: linkse burgers hebben niet alleen meer 'doelgerichte' prikkels dan rechtse burgers (omdat ze de samenleving willen veranderen in plaats van behouden), maar hebben ook meer 'procesmatige' prikkels (omdat met name onder postmaterialisten participatie een expressief doel op zich is). Op grond van de analyses kunnen we bevestigen dat linkse burgers actiever zijn in alle participatievormen, behalve in het stemmen: bij verkiezingen zijn juist rechtse burgers eerder geneigd hun stem uit te brengen.

Volgens de derde hypothese zullen burgers zich meer geprikkeld voelen tot politieke participatie naarmate zij het (meer) oneens zijn met het regeringsbeleid. Wie een groot 'gat' ervaart tussen de eigen beleidsvoorkeur en die van de zittende regering, zal eerder geneigd zijn politiek actief te worden om het beleid te veranderen. De empirische analyses laten zien dat dit effect bestaat voor alle vormen van politieke participatie, behalve opnieuw voor de opkomst bij verkiezingen. Kortom, de eerste analyses wijzen erop dat de mate van politieke participatie niet gelijk is onder verschillende ideologische groepen. Burgers zijn actiever naarmate zij extremer en linkser zijn, maar ook naarmate zij het ideologisch meer oneens zijn met de zittende regering.

Vervolgens richten we ons op de vraag of de institutionele context van invloed is op het niveau van en de ongelijkheid in politieke participatie. Daartoe onderzoeken we de claim dat de mate van politieke participatie hoger en gelijkmatiger is in consensusdemocratieën dan in meerderheidsdemocratieën. Consensusdemocratieën geven immers meer middelen tot participatie aan burgers, met name aan politieke minderheden. Tegenover deze claim formuleren we de verwachting dat politieke participatie juist hoger is in meerderheidsdemocratieën. In die laatste systemen hebben burgers meer prikkels 
om actief te worden, doordat er in politieke zin meer op het spel staat.

De empirische analyses tonen aan dat de institutionele context inderdaad van invloed is op het algemene niveau van participatie. Prikkels om te participeren blijken echter opnieuw doorslaggevender te zijn dan middelen. Burgers in meerderheidsdemocratieën zoeken vaker contact met beleidsmakers, voeren vaker campagne en trachten anderen vaker te overtuigen dan burgers in consensusdemocratieën. Voor opkomst bij verkiezingen, samenwerken voor politieke doelen alsook voor demonstreren vinden we (verrassend) geen significante effecten. We tonen bovendien aan dat de institutionele context niet van invloed is op de ongelijkheid in participatie. Er is geen significant verschil in ongelijkheid tussen consensus- en meerderheidsdemocratieën.

Op grond van deze bevindingen trekken we drie conclusies. Ten eerste zijn verschillende ideologische groepen in ongelijke mate geneigd tot politieke participatie. Dit kan leiden tot problemen voor de kwaliteit van het beleid en de legitimiteit van de democratie. Ten tweede blijken prikkels een belangrijkere oorzaak van politieke participatie te zijn dan middelen. Uiteraard worden burgers pas actief wanneer zij dat willen (prikkels) en kunnen (middelen). Maar prikkels blijken over het geheel een belangrijkere rol te spelen. Dit geldt zowel voor individuele prikkels (ideologie) als voor gemeenschappelijke, contextuele prikkels (institutionele context). Ten derde moet de claim van Lijphart (1999), dat consensusdemocratieën superieur zijn aan meerderheidsdemocratieën, worden herzien. Wanneer we kijken naar (on)gelijkheid in burgerparticipatie, doen meerderheidsdemocratieën niet onder voor consensusdemocratieën. Ze blijken bovendien zelfs beter in staat om grotere groepen burgers tot participatie te verleiden.

\section{Bibliografie}

Lijphart, A. (1999). Patterns of Democracy: Government Forms and Performance in Thirty-Six Countries. New Haven: Yale University Press. 
